\title{
Diacronie
}

Studi di Storia Contemporanea

$\mathrm{N}^{\circ} 36,4 \mid 2018$

Viaggi e turismo nell'Europa del Novecento

\section{Viaggi e turismo nell'Europa del Novecento}

\section{Riccardo Semeraro and Maria Paola Pasini}

\section{(2) OpenEdition}

\section{Journals}

Electronic version

URL: https://journals.openedition.org/diacronie/9998

DOI: 10.4000/diacronie.9998

ISSN: 2038-0925

\section{Publisher}

Association culturelle Diacronie

\section{Electronic reference}

Riccardo Semeraro and Maria Paola Pasini, "Viaggi e turismo nell'Europa del Novecento", Diacronie [Online], N 36, 4 | 2018, document 4, Online since 29 December 2018, connection on 17 February 2022. URL: http://journals.openedition.org/diacronie/9998 ; DOI: https://doi.org/10.4000/diacronie. 9998 
Diacronie

Studi di Storia Contemporanea

$36,4 / 2018$

Viaggi e turismo nell'Europa del Novecento

\section{Strategies of an Italian Spa Company at the Dawn of Mass Tourism. The Recovery of S.A. Terme e Grandi Alberghi di Sirmione in the Second Postwar Period}

Riccardo SEMERARO

Maria Paola PASINI

Per citare questo articolo:

SEMERARO, Riccardo, PASINI, Maria Paola, «Strategies of an Italian Spa Company at the Dawn of Mass Tourism. The Recovery of S.A. Terme e Grandi Alberghi di Sirmione in the Second Postwar Period», Diacronie. Studi di Storia Contemporanea : Viaggi e turismo nell'Europa del Novecento, 36, 4/2018, 29/12/2018,

URL: < http://www.studistorici.com/2018/12/29/semeraro-pasini_numero_36/ >

Diacronie Studi di Storia Contemporanea $\rightarrow$ http://www.diacronie.it

ISSN 2038-0925

Rivista storica online. Uscita trimestrale.

redazione.diacronie@hotmail.it

Comitato di direzione: Naor Ben-Yehoyada - João Fábio Bertonha - Christopher Denis-Delacour - Maximiliano Fuentes Codera Anders Granås Kjøstvedt - John Paul Newman - Deborah Paci - Niccolò Pianciola - Spyridon Ploumidis - Wilko Graf Von Hardenberg

Comitato di redazione: Jacopo Bassi - Luca Bufarale - Gianluca Canè - Luca G. Manenti - Fausto Pietrancosta - Alessandro Salvador - Matteo Tomasoni - Luca Zuccolo

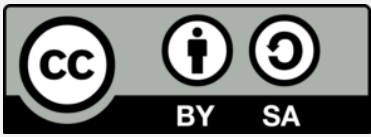

Diritti: gli articoli di Diacronie. Studi di Storia Contemporanea sono pubblicati sotto licenza Creative Commons 3.0. Possono essere riprodotti e modificati a patto di indicare eventuali modifiche dei contenuti, di riconoscere la paternità dell'opera e di condividerla allo stesso modo. La citazione di estratti è comunque sempre autorizzata, nei limiti previsti dalla legge. 


\section{4/ Strategies of an Italian Spa Company at the Dawn of Mass Tourism. The Recovery of S.A. Terme e Grandi Alberghi di Sirmione in the Second Postwar Period}

Riccardo SEMERARO

Maria Paola PASINI

In the aftermath of WWII, the Italian tourism sector, as the rest of the national economy, had to undertake a complex and crucial phase of reconstruction. This essay investigates the second postwar period focusing on the case study of S.A. Terme e Grandi Alberghi di Sirmione. Using documentary material from different archives, the aim is to reconstruct the strategies adopted by the spa company to revive its tourism activities, contextualizing them in the developments of the Garda area. In a crucial phase, when western tourism was acquiring a mass dimension, the new shareholders started afresh from the reconstruction of the accommodation facilities following logics of diversification and innovation.

\section{Introduction}

Today the history of tourism is a consolidated academic discipline that includes a large number of research branches. However, although it has benefited from the development of methods and categories of interpretation of economic history ${ }^{1}$, contributions to cast light on the companies operating in this sector are still in great demand. In 2011 Patrizia Battilani identified two main reasons for the lack of such studies:

in primo luogo la mancanza di una letteratura di riferimento per le imprese del settore dei servizi, molto spesso analizzate con i modelli interpretativi elaborati per il mondo industriale; secondariamente la frammentarietà delle fonti. Infatti, e questo vale in particolar modo per

\footnotetext{
${ }^{1}$ LEONARDI, Andrea, «La storia economica del turismo: un nuovo settore della storia economica», in Società e storia, 99, 2003, pp. 91-104.
} 
l'Italia, la mancanza di grandi imprese di riferimento e dei loro archivi rende molto complessa l'analisi secondo un approccio di business history²

Although in recent years the historiography on the hotel sector has grown significantly, many research branches are still waiting for new studies ${ }^{3}$. One of these strands may be identified by a volume on the relationship between periods of crisis and tourism, and, more specifically, in a chapter by Mary Queck on the capacity of the Hilton group to face a crisis in its process of internationalization ${ }^{4}$. This work seems to recall the interest of economic and business historians for the crisis-recovery theme, which, nevertheless, has not yet seen much involvement of the tourism sector ${ }^{5}$.

With the intention of providing a contribution to fill the abovementioned gaps, this paper reconstructs the strategies implemented by a spa company, S.A. Terme e Grandi Alberghi di Sirmione (SATGAS hereafter), to relaunch its activities at the end of WWII. After a late and slow development compared to the major spa resorts, Sirmione ${ }^{6}-$ a well-known town on the shores of Lake Garda - became a point of reference in local tourism. A great role in this was played by SATGAS that, despite seesawing results, succeeded in conquering a fair share of the Italian spa tourism of the early $20^{\text {th }}$ century. The events of WWII seriously jeopardized the life of the company and represented a turning point in its history: new investments in the accommodation facilities and new strategies were necessary. The present work aims to investigate the crucial choices of the new shareholders that took over the company in the mid-1940s, highlighting their

\footnotetext{
${ }^{2}$ BATTILANI, Patrizia (a cura di), Storia del turismo: Le imprese, vol. 8, Milano, FrancoAngeli, 2011, p. 9. See also: WALTON, John Kimmons, «Prospects in Tourism History: Evolution, State of Play and Future Developments», in Tourism Management, XXX, 6/2009, pp. 783-793.

${ }^{3}$ JAMES, Kevin J., SANDOVAL-STRAUSZ, Andrew K., MAUDLIN, Daniel et al., «The Hotel in History: Evolving Perspectives», in Journal of Tourism History, IX, 1/2017, pp. 92-111.

${ }^{4}$ QUEK, Mary, «Re-organisation of Hilton Hotels International, 1958-1959: A Reactive Crisis Approach», in DRITSAS, Margarita (edited by), Tourism and Crisis in Europe XIX - XXI Centuries. Historical, National, Business Perspectives, Athens, Kerkyra Publications - economia Publishing, 2014, pp. 102-115.

${ }^{5}$ See for example: CASSIS, Youssef, Crises and Opportunities: The Shaping of Modern Finance, New York, Oxford University Press, 2011; NÜTZENADEL, Alexander, CORNELIUS, Torp (edited by), Economic Crises and Global Politics in the 20th Century, London, Routledge, 2014; KOBRAK, Cristopher, WILKINS, Mira (edited by), History and Financial Crisis: Lessons from the 20th century, London, Routledge, 2014. See also the numerous papers presented in the sessions «Recuperación después de la crisis en perspectiva histórica: territorios, industrias y empresas» of the $12^{\text {th }}$ AEHE international congress (Salamanca, 6-9 September 2017) and «Recovering from large scale crisis: strategies, patterns and outcomes, 19th-21th centuries» of the $18^{\text {th }}$ World Economic History Conference (Boston, 29 July - 3 August 2018).

${ }^{6}$ On Sirmione, its history and the sources for its history see: SALVELLI, Guido (a cura di), Sirmione: note descrittive e cenni storici, Brescia, Ildesca, 1952; GUERRINI, Paolo, Sirmione. Appunti critici e documenti per la sua storia: con 7 tavole e 3 disegni, Brescia, Scuola Tipografica Opera Pavoniana, 1957. For further studies on other Italian spa resorts see: BERRINO, Annunziata, Andare per terme, Bologna, Il Mulino, 2014; CUOMO, Erminia, I bagni di Telese fra Ottocento e Novecento. Una stazione termale nell'Italia meridionale, Milano, FrancoAngeli, 2008; SCARDOZZI, Mirella, Un paese intorno alle Terme. Da Bagni di Pisa a San Giuliano Terme, 1742-1935, Pisa, ETS, 2014. For an international perspective on the topic see: WALTON, John Kimmons (edited by), Mineral Springs Resorts in Global Perspectives: Spa Histories, London, Routledge, 2014.
} 
importance in imposing a change of pace on the local spa activity compared to the early $20^{\text {th }}$ century and, in this way, in meeting the challenges related to the transformations of international tourism that in those years was moving towards a mass dimension ${ }^{7}$.

As noted in a recent long-term analysis by Battilani, the $20^{\text {th }}$ century was a positive period for the Italian tourism in which it was possible to see a certain

fragilità delle grandi imprese del settore, una fragilità che diventa evidente proprio nell'epoca d'oro del turismo di massa. [...] Le grandi imprese a caratterizzarsi per una redditività positiva furono quelle dell'hotelliere di lusso, come la Ciga; quelle che seppur storicamente orientate ad una clientela intermedia si portarono verso il lusso, come la Jolly hotel; e, infine, quelle che gestivano i grandi alberghi della più importante città d'affari italiana, cioè Milano. Al contrario nelle mete simbolo del turismo di massa [...] le grandi società svolsero un ruolo assai modesto. Anche perché esse rinunciarono ad occuparsi della fascia intermedia e bassa del mercato, quella degli alberghi di seconda e di terza categoria, che restò così completamente affidato alle piccole e medie imprese famigliari ${ }^{8}$.

The company that is to be taken into consideration in this essay is a case of a tourist enterprise that in the second half of the twentieth century was able to establish itself among the large companies of the sector. Therefore, its study appears as a valuable opportunity to verify the dynamics mentioned above. We intend to do this by focusing on the phase of "spontaneous" mass tourism that goes from the end of WWII to the beginning of the Sixties, when the strong growth of tour operators and charter airlines initiated the era of "organized" mass tourism".

It is worth underlying that the study of a tourist company, as SATGAS, is also an opportunity to enrich the historiography of the economic development of the Benaco area ${ }^{10}$. Although the relevance of Lake Garda in the dynamics of Italian tourism is widely recognized today and its role as center of attraction of mass touristic flows has been repeatedly demonstrated by scientific studies $^{11}$, few works have focused on these aspects by adopting a historical perspective. For this

\footnotetext{
${ }^{7}$ On tourism in the postwar period and the acquisition of this activity of a mass dimension, see chapters 9 and 10 (respective titles Tourism in the Postwar and Mass Tourism) in ZUELOW, Eric G.E., A History of Modern Tourism, London-New York, Palgrave Macmillan, 2016, pp. 149-179.

${ }^{8}$ BATTILANI, Patrizia, «L'industria alberghiera italiana fra Ottocento e Novecento: la fragilità di lungo periodo della grande impresa», in Revista de la Historia de la Economía y de la Empresa, 10, 2016, pp. $102-103$.

${ }^{9}$ ID., «Dal turismo di massa al turismo relazionale: la Riviera romagnola», in L'Italia e le sue Regioni, Treccani, 2015, URL: < http://www.treccani.it/enciclopedia/dal-turismo-di-massa-al-turismo-relazionale-la-rivieraromagnola_\%28L\%27Italia-e-le-sue-Regioni\%29/ > [consulted 1 October 2018].

${ }^{10}$ On the economic history of the Lake Garda area see: PARIS, Ivan, Economia e mercato nell'area gardesana negli ultimi cinque secoli. Il caso di Desenzano, in ONGER, Sergio (a cura di), Il mercato del lago. Desenzano del Garda in età moderna e contemporanea, Brescia, Grafo, 2007, pp. 7-168. See also: COMUNITÀ DEL GARDA, Lo sviluppo economico della regione del Garda: convegno promosso dalla Comunità del Garda e dal Comune di Gardone Riviera, Gardone Riviera, 14-15 ottobre 1967, 2 voll., Verona, Officina grafica Contardi, 1973.

${ }^{11}$ FINOTTO, Carlo Andrea, «Vacanze al lago: il Garda guida la classifica in Italia», in Il Sole 24 Ore, URL:
} 
reason, the research also intends to reconstruct a fundamental page in the history of the Lake Garda area as a region with a strong tourism vocation, whose development process was subject to a significant increase in the second half of the $20^{\text {th }}$ century ${ }^{12}$.

With the purpose of guaranteeing the most solid and exhaustive historical reconstruction possible, three main sources are used: 1) the substantial papers linked to a financing request submitted to IMI by SATGAS in September 1948 and preserved in the historical archive of the same institute ${ }^{13}$;2) the company's financial statements and their attached reports deposited in the historical archive of the Brescia Chamber of Commerce ${ }^{14}$; 3 ) a typewritten document by Guido Bianchi Porro - an important executive of SATGAS in the postwar period - available in the historical archive of the company ${ }^{15}$. Regarding the first, it is worth highlighting that the request, which was sent by the company on 31 August 1948 and received by IMI on 3 September 1948, asked for a $£ 80,000,000$ mortgage for the construction of a new spa center in Sirmione. As for other applications, the financial institution required a series of documents regarding foundation, liens and ownership changes of the company; furthermore, it entrusted its experts with drafting reports on the administrative life and properties of the applicant. Finally, on 28 February 1949, IMI decided to grant a $£ 65,000,000$ mortgage, but SATGAS turned down the offer ${ }^{16}$.

\footnotetext{
< https://is.gd/m0GkFy > [consulted 20 June 2018]; CERTET, Il milieu turistico del Garda bresciano, in UNIONCAMERE LOMBARDIA (a cura di), Collana OPES. Quaderno 14, Milano, Litogì, 1997; PROBRIXIA, Il turismo lacuale alla sfida della complessità turistica, Ciliverghe (BS), Euroteam, 1997; AVANZINI, Patrizia, Politiche di marketing delle imprese alberghiere con particolare riferimento agli insediamenti turistici del lago di Garda, Tesi di laurea in Tecnica e politiche di vendita, Università degli Studi di Verona, Verona, a.a. 1987/1988.

${ }^{12}$ MOCARELLI, Luca, TEDESCHI, Paolo, Note sull'economia delle riviere dei laghi lombardi (secoli XVIII-XX), in VAQUERO PIÑEIRO, Manuel (a cura di), I laghi. Politica, economia, storia, Bologna, Il Mulino, 2017, pp. 47-54. On the tourism history of the Lake see also: PASINI, Pier Giuseppe, Lago di Garda: trent'anni di turismo, Gardone Riviera, Comunità del Garda, 1992; PARIS, Ivan, Conflitti tra residenti e forestieri alle origini dell'industria turistica gardesana, in BELLI, Gemma, CAPANO, Francesca, PASCARIELLO, Maris Ines, La città, il viaggio, il turismo. Percezione, produzione e trasformazione, Napoli, CIRICE, 2017. For a historiographical study on the history of tourism in the province of Brescia see: GREGORINI, Giovanni, Tra Ottocento e Novecento, in TACCOLINI, Mario (a cura di), Il turismo bresciano tra passato e futuro, Milano, Vita e Pensiero, 2001.

${ }^{13}$ The IMI archive is in Via Orazio Amato, 78, 00125 Roma RM (Italy), and is part of the Intesa Sanpaolo Historical Archives. See: IMI s.p.A., Guida all'Archivio Storico dell'Istituto Mobiliare Italiano S.p.A., Roma, Marchesi Grafiche Editoriali, 1998.

${ }^{14}$ The historical archive of the Brescia Chamber of Commerce is in Via Luigi Einaudi, 23, 25121 Brescia BS (Italy). For the inventory see the URL: < http://www.bs.camcom.it/index.phtml?Id_VMenu=282 > [consulted 26 March 2018].

${ }^{15}$ The historical archive of Terme di Sirmione s.p.A. is in Piazza Virgilio, 1, 25019 Sirmione BS (Italy).

${ }^{16}$ Archivio Storico Intesa Sanpaolo, archival heritage of Istituto Mobiliare Italiano (ASI-IMI hereafter), Repertorio Mutui, pr. 3238.
} 


\section{Lake Garda and SATGAS during WWII: occupation and damages}

Sirmione is a famous tourist town on the shores of Lake Garda in the province of Brescia ${ }^{17}$. The thermal exploitation of its spring dates back to the late $19^{\text {th }}$ century, but since the $16^{\text {th }}$ century some scholars had started to describe the characteristic hydrogeological phenomenon - the rising of hot and sulphurous water - that used to take place in the lake, about three hundred meters east the peninsula where Sirmione is located. In 1877, the naturalist Agostino Goiran and the archeologist Giovanni Rambotti were the first to make more precise measurements of the spring, successively published in Storia sismica della provincia di Verona. Some years later, in 1883, don Angelo Piatti - teacher of mathematics and natural sciences at a local high school - achieved significant progress in the study of the phenomenon. Using a special tool he devised - a sounder able to measure depth and temperature of the water - he managed to establish that it actually was a thermo-sulphurous spring ${ }^{18}$.

In the following years, despite the great efforts of the mayor of Sirmione - Gaetano Bocchio and the strong interest of a couple of entrepreneurs, the exploitation of the spring was held back by the constraints of the ministerial bureaucracy. Only in 1889, Angelo Gennari - a local young fish seller - using rudimentary tools and opening a small hotel, succeeded in using the spa waters of the area for touristic purposes. On the basis of this, Gennari was able to achieve two important results: first, he won the competition and took over the other entrepreneurial ventures that, at the end of the century, were finally established with the concession of the spring by the Ministry; second, in the first $20^{\text {th }}$ century, he built a series of touristic facilities that carved out a remarkable position in the elitist tourism of the belle époque ${ }^{19}$.

\footnotetext{
${ }^{17}$ Lake Garda and its shores are divided into three provinces: Brescia, Trento and Verona.

${ }^{18}$ ONGER, Sergio, Gli stabilimenti termali nella Lombardia orientale fra Otto e primo Novecento, in ONGER, Sergio, Una provincia operosa. Aspetti dell'economia bresciana tra XVIII e XX secolo, Milano, FrancoAngeli, 2011, pp. 99100. See also: GORIAN, Agostino, Storia sismica della provincia di Verona: meteorologia endogena, Verona, Civelli, 1880, pp. 106-107; PIATTI, Angelo, «La sorgente termo-solforosa di Sirmione sul lago di Garda», in: Bollettino del Regio Comitato Geologico d'Italia, 5-6, 1887, pp. 191-193; ID., «La sorgente termo-solforosa di Sirmione sul lago di Garda", in Bollettino del Regio Comitato Geologico d'Italia, 9-10, 1889, p. 288. Regarding Giovanni Rambotti, to whose memory the archeological museum of Desenzano del Garda (an important town on the shores of Lake Garda) is dedicated, see: DE MARINIS, Raffaele Carlo, «Giovanni Rambotti (1817-1896)», in Institutional website of the town of Desenzano del Garda, URL:

$<\mathrm{http}: / /$ comune.desenzano.brescia.it/italian/Museo_biografia_gr.php?iExpand1=593 > [consulted 18 May 2018]. On the source of Sirmione, called Boiola, and the properties of its water see: Anon., La sorgente Boiola di Sirmione, Sirmione, Terme e Grandi Alberghi di Sirmione s.p.A., 1973.

${ }^{19}$ ONGER, Sergio, Gli stabilimenti termali nella Lombardia orientale fra Otto e primo Novecento, cit., p. 102. On the spa activity in Sirmione between the $19^{\text {th }}$ and $20^{\text {th }}$ centuries see also: FROSIO, Fulvio, Il termalismo nel bresciano nel XIX secolo, Tesi di laurea in Economia e commercio, Università degli Studi di Brescia, Brescia, a.a. 1995/1996, pp. 227-279. On Angelo Gennari see: FAPPANI, Antonio, «Angelo Gennari», in Enciclopedia Bresciana, URL: < http://www.enciclopediabresciana.it/enciclopedia/index.php?title=GENNARI_Angelo > [consulted 18 May 2018].
} 
In 1921, as a consequence of the problems caused by the Great War, the Gennari family accepted the entry of new partners into their company, which became a public limited company and acquired the business name S.A. Regie Terme e Grandi Alberghi di Sirmione (SATGAS since $1941)^{20}$. In the Thirties, despite seesawing results, the company was central to the tourism of Sirmione controlling both the two spa centers (Regie Terme and Stabilimento Boiola) and the major hotels of the town (Terme, Boiola and Sirmione) ${ }^{21}$. The life of SATGAS was again seriously threatened by the events of WWII. In particular, between 1943 and 1946, when its structures and strategies were turned upside-down by the damages caused by the German and then AngloAmerican requisitions ${ }^{22}$.

During the war, the bombings caused considerable devastation to the province of Brescia and in particular to its capital: Brescia was categorized as "a seriously damaged city". According to the information acquired from the technical office of the Municipality, the buildings hit by the bombs were 35,198 in the city center. Around 7,000 families needed assistance for a total of 28,000 people ${ }^{23}$. Also other provincial towns were affected by air raids with consequences on houses and infrastructures. On the Chiese river in Montichiari, as well as on the Oglio and Mella rivers in Soncino and Pralboino respectively, several bridges were destroyed. Serious damages were registered in Valsabbia and Valcamonica (i.e. the bridges on the Nozza and Gratacasolo creeks) and important stretches of railway line were hit in Rezzato and Desenzano ${ }^{24}$. Regarding Lake Garda, there had been no significant bombings except for those in the southern area where the railway line ran. However, between 1943 and 1945, numerous historical buildings were requisitioned by the Social Republic to house Fascist and Nazist ministers and offices. Furthermore, some hotels had been transformed into hospitals; perhaps, for this very reason, according to the Geneva International Convention, the lake was preserved from the raids ${ }^{25}$.

The provincial economic conditions were extremely critical. Both agriculture and industry faced significant problems. For the former, the hardest challenge was to find a balance between

\footnotetext{
${ }^{20}$ NANNI, Simona, Passione Pura, Colombare di Sirmione (BS), Terme di Sirmione s.p.A., 2009, pp. 25-27.

${ }^{21}$ TOURING CLUB ITALIANO, Guida pratica ai luoghi di soggiorno e di cura d'Italia. 3: Le stazioni idroterapiche, Milano, Touring Club Italiano, 1936, p. 196.

${ }^{22}$ NANNI, Simona, op. cit., pp. 29-30.

${ }^{23}$ SEMERARO, Riccardo, Society and Welfare Community in Early Postwar Brescia, in ANNI, Rolando, GREGORINI, Giovanni, PASINI, Maria Paola (a cura di), Gli Alleati a Brescia tra guerra e ricostruzione. Fonti, ricerche, interpretazioni, Milano, FrancoAngeli, 2018, pp. 65-89. On Brescia and its province after the Liberation see also: PASINI, Maria Paola, Brescia 1945, Brescia, Grafo, 2015; ID. (a cura di), Ricostruire sulle macerie. La rinascita di Brescia nel secondo dopoguerra (1945-1951), Gavardo (BS), Archivio storico della Resistenza bresciana e dell'Età contemporanea, 2013; BOTTERI, Inge (a cura di), Dopo la liberazione. L'Italia nella transizione tra la guerra e la pace: temi, casi, storiografia, Brescia, Grafo, 2008, pp. 295-379.

${ }^{24}$ GALLI, Lodovico, Incursioni aeree nel bresciano (1944-1945), Brescia, Edizioni del Moretto, 1980.

${ }^{25}$ PASINI, Maria Paola, Il turismo sul lago di Garda nel secondo dopoguerra, tra ricostruzione, promozione e rivendicazioni territoriali (1945-1955), in BERRINO, Annunziata (a cura di), Storia del turismo. Annale, vol. 11, Milano, FrancoAngeli, forthcoming. On Brescia and its province during the Italian Civil War see: ANNI, Rolando, PALA, Elena (a cura di), 1943-1945: attendere, subire, scegliere, Gavardo (BS), Archivio storico della Resistenza bresciana e dell'Età contemporanea, 2014.
} 
high input costs and low prices for produce, revitalizing the process of mechanization and finding solutions for the overabundance of labor. In the latter sector, the biggest problems were due to the process of reconversion, particularly intense and difficult for the leading local arms industry. Unemployment reached incredible levels: despite the flexibility and adaptability of local small enterprises and artisan workshops, around 40-50,000 jobs were lost in the secondary sector. Several demonstrations took place in the provincial capital, where around 10,000 people were unemployed ${ }^{26}$.

The Allies, with the $5^{\text {th }}$ American and the $8^{\text {th }}$ British armies, reached Lake Garda and Brescia at the end of April 1945 where they immediately took care of the most pressing needs: refugees, health issues, food, public order, reconstruction of infrastructures (roads, bridges, railway) and safeguarding of artistic heritage. The Allied government led the province until 31 December 1945, during these months the AMG supported the local reconstruction with a significant operational and economic contribution. Just for the provincial capital more than $£ 100$ million were allocated and gradually used to solve the most urgent problems that in several occasions also involved the city's tourist and cultural heritage. In this sense, particularly significant was the aid provided for the artistic goods under the directives of the MFAA subcommittee: $£ 100,000$ were allocated for the Sala delle Dame by Moretto in Palazzo Salvadego ${ }^{27}$.

When war operations were over, the Allied soldiers which were deployed in the area were housed on the shores of Lake Garda where the great availability of accommodation facilities represented an important logistic resource. For example, an American infantry contingent, the Blue Devils, stayed a few months in the hotels of Desenzano. These soldiers, as many others, were equipped with detailed guides provided by their command to better understand the region. In this way, the Anglo-American militaries actually became the first tourists of the Lake in the postwar period: they sent home thousands of photographs praising the local beauties and making the Garda famous in their homeland. However, their presence also implied significant problems for the local tourist operators. As a matter of fact, the AMG seized the accommodation facilities and used them as logistic hubs for their own troops. Thus, even after 25 April 1945, for several months, it was not possible to start the needed restoration of the area, and the hotels were subject to such intense use that they suffered further damage ${ }^{28}$.

\footnotetext{
${ }^{26}$ GREGORINI, Giovanni, Problemi e scelte nell'economia e nella società bresciane dopo la liberazione, in BOTTERI, Inge (a cura di), Dopo la liberazione. L'Italia nella transizione tra la guerra e la pace: temi, casi, storiografia, Brescia, Grafo, 2008, pp. 297-310. On the economic conditions of the province of Brescia see also: TREZZI, Luigi, Gli anni della ricostruzione dell'economia bresciana (1945-1950), in RUMI, Giorgio, MEZZANOTTE, Gianni, COVA, Alberto (a cura di), Brescia e il suo territorio, Milano, Cariplo, 1996, pp. 471-502.

${ }^{27}$ PASINI, Maria Paola, Gli Alleati a Brescia: uomini, funzioni, relazioni, in ANNI, Rolando, GREGORINI, Giovanni, PASINI, Maria Paola (a cura di), Gli Alleati a Brescia tra guerra e ricostruzione, cit., pp. 39-51.

${ }^{28}$ ID., I soldati alleati: i primi "turisti" del dopoguerra sul lago di Garda, in Ibidem, pp. 155-159.
} 
On the basis of the information included in a survey of the Ministry of Industry and Commerce, carried out by the Italian Central Statistical Institute between 1946 and 1948, it is possible to have a complete picture of the local companies that were occupied by the Allies after the German occupation $^{29}$. The survey - preserved in the historical archive of the Brescia Chamber of Commerce - tells us that 41 companies were seized in the province and the great majority $(31)^{30}$ were accommodation facilities in the Garda area: 1 in Manerba, 5 in Desenzano del Garda, 5 in Toscolano Maderno, 7 in Gardone Riviera, 7 in Salò, 10 in Sirmione ${ }^{31}$. These structures represented the most suitable solutions for dimensional and logistic reasons as they could host a great number of soldiers and were located in a strategic area, not far from important cities (i.e. Milan, Brescia, Trento, Verona) and routes.

The problems for SATGAS started on 8 September 1943, when its hotels and spa facilities were occupied by German troops and after the Liberation, in 1945, by the Allies. In addition to the requisition and inactivity of the hotels, the German occupation also involved the complete refit of the spa with the purpose of using it as a lithograph for the production of $£ 1,000$ banknotes. Other serious problems were caused by the total lack of maintenance on the lake and spring pipes, and by a British air raid ${ }^{32}$. Overall, the company's real estate properties were affected by serious damages to shutters, windows, basins, and electrical, plumbing and thermal systems. Even the roof beams were removed and the wooden floors torn apart to be used as firewood for the troops. In total the reported damages amounted to $£ 24,238,175$ and their subdivision between periods of occupation is shown in Table $1^{33}$.

Table 1. Damages to SATGAS: German and Allied occupations.

\begin{tabular}{|c|c|}
\hline \multicolumn{2}{|c|}{ Damages caused by the German occupation } \\
\hline Buildings & $£ 6,000,000$ \\
\hline Furnitures & $£ 9,370,900$ \\
\hline \multicolumn{2}{|c|}{ Damages caused by the Allied occupation } \\
\hline Hotel Terme & $£ 5,585,075$ \\
\hline Hotel Boiola & $£ 3,282,200$ \\
\hline Total & $£ 24,238,175$ \\
\hline
\end{tabular}

Source: ASI-IMI, Serie Mutui, pr.3238, SATGAS, RAmm, p. 3.

\footnotetext{
${ }^{29}$ Archivio Storico della Camera di Commercio di Brescia (ASCBs hereafter), Sezione II: 1943-1963 - Cat. XXII, b. 776 , f. 2, «Indagine statistica sullo stato delle aziende industriali e commerciali requisite od occupate da autorità alleate o italiane».

${ }^{30}$ Actually, the companies occupied in the Garda area were 35. Besides hotels, restaurants and trattorias there were other kinds of businesses: Autorimessa F.lli Ferrari (Desenzano), Enopolio della Valtenesi (Manerba), Convalescenziario S. Maria (Salò), Istituto profilattico Cremonese (Toscolano Maderno).

${ }^{31}$ ASCBs, Sezione II: 1943-1963 - Cat. XXII, b. 776, f. 2, «Aziende industriali e commerciali requisite dagli Alleati o da autorità italiane (partigiani, ecc)».

${ }^{32}$ Archivio Storico Terme di Sirmione s.p.A. (ASTS hereafter), «Cronistoria della sorgente "Boiola”, Guido Bianchi Porro, 28/11/1967 (CSB hereafter)», p. 32.

${ }^{33}$ ASI-IMI, Serie Mutui, pr. 3238, SATGAS, «Relazione amministrativa sulla SATGAS, E. Bonardi, 27/11/1948 (RAmm hereafter)», p. 3.
} 
It was possible to really start the reconstruction in 1946 only, when the Allies left. Locals focused their attention on the restoration of touristic facilities and reorganization of the lake navigation. An interprovincial body in charge of coordinating the local development, called Ente del Garda ${ }^{34}$, was established and extensive debates on the future of the Lake took place on local newspapers. At the center of the stage there were some major issues regarding the touristic future of the area: 1) reactivation of hospitality facilities, in particular of historic hotels; 2) resumption of logistic connections, especially lake navigation; 3) strengthening of the unitary promotion of Lake Garda image, with a special attention for foreign countries; 4) territorial reorganization of the area in order to constitute a homogeneous "Garda Region", a union of the four provinces on the shores of the lake (Brescia, Verona, Trento and Mantua) ${ }^{35}$.

\section{Reconstruction: renovation, innovation and diversification}

At the end of the war, SATGAS was about to experience a very convulsive and eventful phase of its history. The first of a series of important transformations occurred in 1945 and was the change of ownership that brought the shares of the company into the hands of a new group of shareholders. A group of industrialists from Brescia, Milan and Veneto ${ }^{36}$, took over the business replacing another one from Brescia that had acquired SATGAS only three years earlier from the Gennari family. The count Rambaldo di Collalto ${ }^{37}$, the notary Giovanni Bossoni ${ }^{38}$, the accountant Pasquale Nembri and Giacinto Turlini ${ }^{39}$ were the major shareholders of SATGAS. The technicaladministrative organization was entrusted to a general manager, the accountant Alfonso Froner,

\footnotetext{
${ }^{34}$ On Ente del Garda see also: CANEPA, Luigi, CERESA, Pierlucio, PASINI, Pier Giuseppe (a cura di), La Comunità del Garda. Una sana utopia, Gardone Riviera, Comunità del Garda, 1992; ONGER, Sergio (a cura di), La Comunità del Garda: lo sviluppo di un'idea (1955-2005), Gardone Riviera, Comunità del Garda, 2005.

${ }_{35}$ PASINI, Maria Paola, Il turismo sul lago di Garda nel secondo dopoguerra, tra ricostruzione, promozione e rivendicazioni territoriali (1945-1955), cit.

${ }^{36}$ In particular the members from the Veneto region seemed predominant and had substantial interests in the textile sector, as demonstrated by the fact that several of them were in the boards of directors and auditors of companies like Cotonificio di Mogliano, Industriale Serica, Torcitura di Borgomanero and Torcitura Grezzago Zoja. In 1952 and 1960, when SATGAS's board of directors accounted new members this situation was even more evident. See the database imita.db, URL:

$<$ http://imitadb.unisi.it/ammi.asp?IdSoc=29554 > [consulted 13 October 2018].

${ }^{37}$ On the noble origins of the Collalto family see: BENZONI, Gino, "COLLALTO, Rambaldo», in Treccani. Dizionario biografico degli italiani, vol. 26, URL: < http://www.treccani.it/enciclopedia/rambaldocollalto_(Dizionario-Biografico)/ > [consulted 23 May 2018]; DEROSAS, Renzo, "COLLALTO, Antonio Rambaldo", in Ibidem, URL: < http://www.treccani.it/enciclopedia/antonio-rambaldo-collalto_(DizionarioBiografico)/ > [consulted 23 May 2018]; Anon., «Sirmione, addio al presidente delle Terme» in Gazzetta di Mantova, URL: < https://is.gd/TtoYF > [consulted 23 May 2018].

38 On Bossoni see: FAPPANI, Antonio, «Bossoni», in Enciclopedia Bresciana, URL: < http://www.enciclopediabresciana.it/enciclopedia/index.php?title=BOSSONI > [consulted 23 May 2018].

${ }^{39}$ Before becoming shareholder of SATGAS, in the period 1931-1944, Turlini had been director of S.A. Agricola Industriale del Lino established by S.A. Linificio e Canapificio Nazionale. By Turlini see: TURLINI, Giacinto, "Crisi agricola e nuovi orientamenti produttivi», in Commentari dell'Ateneo di Brescia per l'anno 1956, CLV, 1958, pp. 203-219.
} 
also director of Terme di Roncegno (Trentino) and auditor of Alberghi Rainalter -, who was assisted by a technical director, the engineer Guido Bianchi Porro ${ }^{40}$.

Table 2. SATGAS's shareholders in 1948 - Source: ASI-IMI, Serie Mutui, pr. 3238, SATGAS, RAmm, p. 2.

\begin{tabular}{|l|r|}
\hline \multicolumn{1}{|c|}{ Shareholders (surname and name) } & n. of shares \\
\hline Banfi Gianfranco & 2,742 \\
\hline Bossoni Giovanni & 11,000 \\
\hline Caligaris Luigi & 1,239 \\
\hline Carcano Carlo & 595 \\
\hline Carioli Fromeno & 2,000 \\
\hline Collalto Rambaldo & 8,588 \\
\hline Crosato Guido & 1,200 \\
\hline Frambini Giuseppe & 4,496 \\
\hline Gris Janny & 1,500 \\
\hline Gris Teresina & 3,610 \\
\hline Lupo Carluigi & 300 \\
\hline Monaro Piero & 1,096 \\
\hline Motta Pietro & 6,680 \\
\hline Nembri Pasquale & 8,587 \\
\hline Turlini Giacinto & 10,000 \\
\hline Rossi Eugenio & 1,190 \\
\hline Zadra Arrigo & 3,806 \\
\hline Zanotti & 1,371 \\
\hline Total & $\mathbf{7 0 , 0 0 0}$ \\
\hline
\end{tabular}

Table 3. SATGAS's board of directors in 1948 - Source: ASI-IMI, Serie Mutui, pr. 3238, SATGAS, RAmm, p. 2.

\begin{tabular}{|l|l|}
\hline \multicolumn{1}{|c|}{ Member } & \\
\hline Rambaldo di Collalto & Chairman \\
\hline Nembri Pasquale & Vice-Chairman \\
\hline Bossoni Giovanni & Member \\
\hline Motta Pietro & Member \\
\hline Zadra Enrico & Member \\
\hline Banfi Franco & Member \\
\hline Crosato Guido & Member \\
\hline
\end{tabular}

Table 4. SATGAS's board of auditors in 1948 - Source: ASI-IMI, Serie Mutui, pr. 3238, SATGAS, RAmm, p. 2.

\begin{tabular}{|l|l|}
\hline \multicolumn{1}{|c|}{ Surname and name } & \multicolumn{1}{|c|}{ Position outside the company } \\
\hline Regazzoli Leone & Professional \\
\hline Spezza Pietro & Professional \\
\hline Corsani Diego & Official of the Ministry of Finance \\
\hline
\end{tabular}

${ }^{40}$ ASI-IMI, Serie Mutui, pr. 3238, SATGAS, RAmm, pp. 1-2; Ibidem, «Relazione sugli accertamenti eseguiti presso la SATGAS, G. Cappon, 10/1948 (RAcc hereafter)», p. 1. 
After the departure of the Allies, the new shareholders undertook the relaunch of SATGAS through investments mainly aimed at the restoration of old accommodation facilities or the construction of new ones ${ }^{41}$. However, raising the necessary funds was not easy: after years of inactivity and deterioration of the facilities, considerable resources were needed to relaunch the tourism business and to develop its potential ${ }^{42}$. The paths followed were essentially four: 1) capital increases, 2) establishment of a reserve fund, 3) issuance of bonds, 4) obtainment of a long-term mortgage.

Significant efforts were made by the shareholders with numerous and substantial capital increases. In 1946 the share capital was increased from $£ 600,000$ to $£ 6,000,000$ issuing 36,000 shares at par value of $£ 150$ each $^{43}$. Successively, without changes in the par value of the shares, the share capital reached $£ 10,500,000$ in $1947^{44}, £ 31,500,000$ in $1948^{45}, £ 63,000,000$ in $1949^{46}$ and $£ 88,200,000$ in $1951^{47}$.

The second and third strategies were exploited synergistically with respect to the first one. The two bond loans were issued by SATGAS in conjunction with the capital increases of 1948 and 1949 and never exceeded the total amount of the share capital ${ }^{48}$. The reserve fund - created in 1946 and denominated "Reserve fund for revaluations" 49 - was partially used to distribute for free to the shareholders half of the new shares issued with the capital increase of $1949^{50}$.

Lastly, in 1949, SATGAS signed a long-term mortgage with Cassa di Risparmio delle Province Lombarde. Even though the precise features of this operation remain unknown, it is possible to make a couple of considerations. First of all, this represented the happy ending of a long research began at the end of the war and, probably, the reason why SATGAS decided to decline the offer received from $\mathrm{IMI}^{51}$. Secondly, the signing of the loan allowed the company to take an important

\footnotetext{
${ }^{41}$ These projects, their progress and the improvements at which they were aimed were mentioned also in specialist publications, i.e. see: Anon., «Terme di Sirmione», in Turismo e alberghi, XX:1, luglio 1947, p. 6.

${ }^{42}$ Just considered that in 1948, when all the interventions were completed, except for the construction of the new spa center, the costs amounted to $£ 204.983,000$ : $132.677,000$ for purchases and construction, £ $38,297,000$ for plants and equipment, $£ 34.019,000$ for furnishings. See: ASI-IMI, Serie Mutui, pr. 3238, SATGAS, RAmm, pp. 3-4.

${ }^{43}$ ASCBs, Registro società commerciali presso Cancelleria del Tribunale di Brescia (RCT hereafter), n. 200, «Verbale di deposito di bilancio (VDB hereafter), 23/4/1947».

${ }^{44}$ Ibidem, «VDB, 20/6/1948».

${ }^{45}$ Ibidem, «Trascrizione 31, 15/1/1949».

${ }^{46}$ Ibidem, «Trascrizione 1705, 31/10/1949».

${ }^{47}$ Ibidem, «Trascrizione 469, 10/4/1951».

${ }^{48}$ The bond loans, both for $£ 31,500,000$, were carried out issuing 31.500 bonds with a nominal value of $£$ 1,000 each, which were issued at par by the board of directors with an interest rate of $7 \%$ per annum net of any tax and commission fee. See: Ibidem, "Trascrizione 31, 15/1/1949»; Ibidem, "Trascrizione 1705, $31 / 10 / 1949 »$.

${ }^{49}$ It was created through the budget surplus $(£ 21,749,737)$ deriving from the revaluation of immovable properties, furnishings and machineries in order to adjust their book value to their real one. See: Ibidem, «VDB, 23/4/1947».

${ }^{50}$ Ibidem, «Trascrizione 1705, 31/10/1949».

${ }^{51}$ Ibidem, «VDB, 23/4/1947».
} 
step towards the consolidation of its exposure to banks and, more generally, of its financial situation $^{52}$

On the basis of the financial strategies described hereabove, between October and November 1946, the reconstruction of the Hotel Boiola, which was in ruins, and the complete renovation of the Hotel Terme finally started: the expenditure forecasts for the two were $£ 14,195,000$ and $£ 82,443,000$ respectively. Furthermore, the construction of a new spa center - also available to the guests of the other accommodation facilities of Sirmione - was planned. The new building was projected with a capacity of 800 beds and the cost estimate was $£ 89,649,000$. However, the interventions related to this real estate operation required great efforts due to the considerable costs and the architectural difficulties determined by the marshy nature of the land of its seat that caused many problems and expenses especially for the construction of the foundations. Thus, the construction was interrupted in 1947 in light of the precarious economic and financial results achieved by the company in that year ${ }^{53}$.

In 1946, the rebirth of the Boiola spring took place: as a matter of fact, after three years of inactivity, the reactivation of the pumps and the duct in the lake enabled the resumption of the spa activity using the small spa area of the Hotel Sirmione, the only one that could be restored quickly ${ }^{54}$. Completely renovated in 1938 and only slightly damaged during the war ${ }^{55}$, the Hotel Sirmione was a three-storey masonry construction with an irregular plan, resulting from constructions carried out in different periods. It was in the main square of Sirmione, near the pier where the steamboats used to moor, and overlooked the lake with its terrace and garden. It was a first-class hotel offering quality services and it was supposed to attract a medium-high range clientele. The hotel could count on 42 rooms (each of which with hot and cold water), 60 beds, 8 bathrooms, 12 toilets, 10 rooms for staff, 6 state rooms (hall, dining and living rooms), as well as other services. The furnishing and finishing of the entire structure were of a good level without having luxurious features ${ }^{56}$.

If 1946 was important for the general setting and the beginning of the entire reconstruction process, the following two years were crucial for completing the infrastructural base of the spa resort. As a matter of fact, after having been both increased in terms of size and capacity, the Hotel Boiola and the Hotel Terme - renamed Hotel Fonte Boiola and Grand Hotel Terme reopened in May and September 1947 respectively ${ }^{57}$.

\footnotetext{
${ }^{52}$ Ibidem, «VDB, 13/5/1950».

${ }^{53}$ ASTS, CSB, p. 32; ASI-IMI, Serie Mutui, pr. 3238, SATGAS, RAmm, pp. 3-4; Ibidem, «Relazione sul progetto del nuovo stabilimento termale di A. Bordoni»; ASCBs, RCT, n. 200, «VDB, 20/6/1948».

${ }^{54}$ ASTS, CSB, p. 32.

${ }^{55}$ The hotel was occupied by officals.

${ }^{56}$ ASI-IMI, Serie Mutui, pr. 3238, SATGAS, RAcc, p. 8.

${ }^{57}$ ASTS, CSB, p. 32.
} 
The Grand Hotel Terme was a three-storey building with a perfectly rectangular plan that was completely refitted and modified. Despite not being located in the most beautiful position in Sirmione ${ }^{58}$, substantial investments were made on the hotel considering that it was transformed from a family pension into a first-class facility with special luxury features ${ }^{59}$. At the end of the renovation, the hotel had 63 rooms with 90 beds, 19 bathrooms (en-suite and shared), 23 toilets, 16 staff rooms, 9 lounges and state rooms and other services. On the ground floor, there were the dining rooms, reception desk and office, lobby, smoking and writing lounge, and a large ballroom. On the first and second floors, there were rooms, bathrooms and toilets, whereas the staff rooms were built in the roof space ${ }^{60}$. The spa area was easily accessible by the guests from the corridor of the first floor and it had been built in a new wing of the building which was L-shaped and reached the lake shore. It was equipped with 11 spa cubicles for baths, muds and inhalations: the cubicles were luxurious, with a shower and a toilet in addition to the bath and the spa bed, finished in green tiles and equipped with a telephone system protected against the damages caused by sulphurous gases. The mud tanks - connected with a hoist to the pier where the boats transporting the mud from the mineralization tanks used to dock - and the heated storage cupboards completed the ward. The facilities of the hotel were located in the rooms under the spa department, while the part facing the lake was transformed into a tavern for dinner dances with a bar and a terrace overlooking the lake ${ }^{61}$. The result achieved through the renovation and modernization works was a very high-quality environment, designed to satisfy the most demanding guests, in search of the most modern services and comforts. In other words, the Grand Hotel Terme became the real spearhead of the spa company: the interiors were rearranged ${ }^{62}$ and equipped with simple but elegant furniture and advanced services to provide the staff with what was necessary to attend to customers ${ }^{63}$.

The Boiola was a second-class hotel, located along the lakeside near the Grand Hotel Terme, along the access road to Sirmione. This hotel met second-rate standards, though its décor was closer to third-rate ones, and could count on elegant state rooms renovated immediately at the

\footnotetext{
${ }^{58}$ The hotel is located on the shore of the lake at the end of the driveway to Sirmione, before the door that leads into the village and near the Scaliger Castle. On the castle of Sirmione see: BOSCHI, Ruggero, FASSER, Marco, TRECCANI, Gian Paolo, Sirmione: la rocca scaligera, Brescia, Grafo, 1981.

${ }^{59}$ Although not lavish, the furniture was very modern and particularly elegant: it was specially designed by the well-known and appreciated Venetian architect Angelo Scattolin. By Scattolin see: SCATTOLIN, Angelo, Problemi del restauro nell'architettura d'oggi: lezione di apertura tenuta dal prof. arch. Angelo Scattolin, Venezia, Tipografia Emiliana, 1947; ID., Semantica dell'urbanistica a Venezia, Milano, Edizione istituto propaganda internazionale, 1962.

${ }^{60}$ ASI-IMI, Serie Mutui, pr. 3238, SATGAS, RAcc, pp. 6-7.

${ }^{61}$ Ibidem, pp. 7-8.

${ }^{62}$ Crucial was the grouping of all the kitchen facilities in a corner of the building in order to directly serve both the two indoor dining rooms, the outdoor restaurant in the garden towards the lake, and also the tavern and the terrace of the second floor.

${ }^{63}$ SILVESTRI, Giuseppe, «Alberghi e terme a Sirmione», in Turismo e alberghi, XX, 6 dicembre 1947, pp. 260262.
} 
end of the war. Also in this case, through the investments made by the new shareholders, the building underwent a complete renovation; a new dining room, kitchen and garage were built; the spa area was enlarged and perfected, almost all the furnishings were renovated, and the running water system was made available in all the rooms ${ }^{64}$. At the end of the works, the Boiola could thus count on 44 rooms (each of them with cold running water), 60 beds, 2 bathrooms, 4 toilets, 3 state rooms, 2 rooms for staff and other services. The spa department, located in a specific section of the ground floor, was equipped with 10 mud baths, 1 cubicle for inhalations, 1 for nebulization, 1 for humage. Also in this case, the equipment and the furniture did not excel, but they were in a good state of maintenance and cleanliness ${ }^{65}$.

In the winter 1947-48, a Center for Rhinogenic Deafness was opened in a specially purchased, enlarged and equipped villa (Villa Arduino). The Center was located north of Sirmione and stood in an elevated position in a beautiful park of over 8,000 square meters. The building was composed of a dozen rooms and through the investments of SATGAS it was enlarged with the construction of a new wing, 2 floors above ground, where the spa cubicles were placed. On the ground floor there were 2 waiting rooms and 3 cubicles for inhalations, pulverization and humage; another waiting room, two examination rooms and other 6 cubicles were available on the first floor; services and accommodation for the caretaker were in the basement. The cutting edge of this new structure - the first one in Italy - was its innovative equipment: the center was equipped with a very modern "audiometer" for determining the type and degree of deafness and other advanced devices ${ }^{66}$.

In October 1948, under the aegis of the notary Giovanni Bossoni - member of SATGAS's board of directors and within few years vice-president - the construction of the new spa center was resumed. The work was entrusted to the construction company Dusi of Verona, under the coordination of the engineers Michele Manara and Guido Bianchi Porro. Although the grand initial projects were downsized for both economic and bureaucratic reasons, the investment made by SATGAS was of primary importance and enabled it to prepare the ground for its success in the following decades. The new spa center was equipped with a large reception room, 2 rooms for medical examination, 5 bath cubicles, 8 mud-baths cubicles with a reaction room, 1 room with 6 inhalation devices, 3 humages devices, 1 nebulization room, 1 cubicle for vaginal irrigation, 1 room for towel warming and staff, 1 room for mud heating. Moreover, there were a laundry, a cloakroom and a technical room in the basement, as well as 24 tanks for the maceration of the mud outdoors ${ }^{67}$.

\footnotetext{
${ }^{64}$ Ibidem, p. 260.

${ }^{65}$ ASI-IMI, Serie Mutui, pr. 3238, SATGAS, RAcc, pp. 8-9.

${ }^{66}$ Ibidem, p. 9.

${ }^{67}$ ASTS, CSB, pp. 33-34.
} 


\section{Success}

As can be easily inferred from the information on the substantial investments made to restore SATGAS's facilities, the resumption of tourism in Sirmione was not straightforward. The $1946 \mathrm{spa}$ season, during which SATGAS could only use the Hotel Sirmione, registered 625 spa guests and 51 patients for the treatment of rhinogenic deafness ${ }^{68}$. In 1947 the entry into service of the Hotel Fonte Boiola allowed to increase the revenues significantly, but the impossibility of exploiting the Grand Hotel Terme and the sums invested to put it back into efficiency reduced the profits, as a consequence the financial statements reported a loss of $£ 395,356^{69}$.

The situation, at least from a financial point of view, did not change even in the immediate following years, when SATGAS registered losses that were promptly postponed to subsequent fiscal years or broke-even only by substantially reducing amortizations ${ }^{70}$. However, something was changing: the number of tourists and patients who chose the company's facilities was continuously growing (Graph 1) and Sirmione, with Gardone Riviera ${ }^{71}$, was becoming a point of reference for the tourism resurgence of Lake Garda. In this sense, not only were the figures of arrivals and night stays of Italian tourists particularly significant, but also those regarding foreign guests. Even though, in 1951, the German clientele, which in the pre-war period had constituted $65 \%$ of the local tourist movement, represented only $5 \%$, there were encouraging signs: growing numbers of tourists from England, Sweden, Austria, USA, Belgium, France and Holland were returning to the Lake (Graphs 2 and 3$)^{72}$.

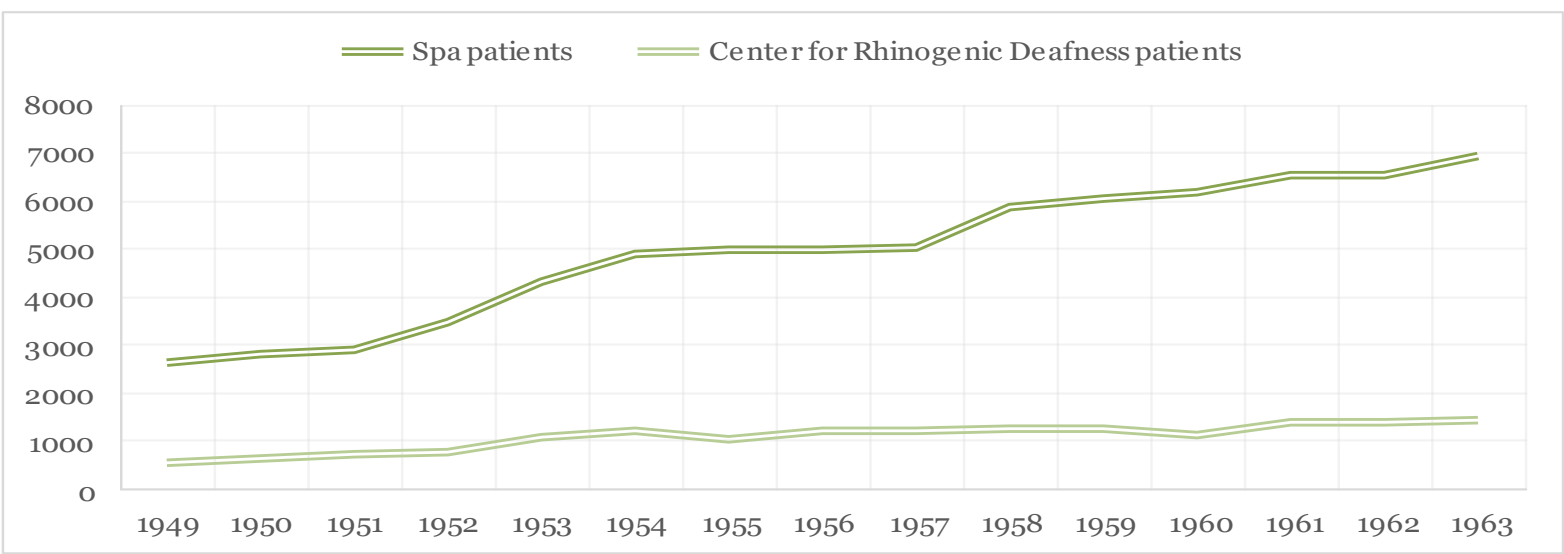

Graph 1. SATGAS's patients (1949-1963) - Source: ASTS, CSB, pp. 35-36 (data processed by the authors).

\footnotetext{
${ }^{68}$ Ibidem, p. 32.

${ }^{69}$ ASCBs, RCT, n. 200, «VDB 20/6/1948».

${ }^{70}$ Ibidem, «VDB 7/5/1949»; Ibidem, «VDB 13/5/1950»; Ibidem, «VDB 10/5/1951»; Ibidem, «VDB 17/3/1952»; Ibidem, «VDB 30/4/1953».

${ }^{71}$ On Gardone Riviera in the postwar period see: SILVESTRI, Giuseppe, «Gardone e la sua Riviera», in Turismo e alberghi, XXI, 8-9, agosto-settembre 1948, pp. 362-366.

${ }^{72}$ RAPETTI, Achille, «La ripresa turistica del Garda», in Turismo e alberghi, XXIV:4, aprile 1951, pp. 201-206.
} 


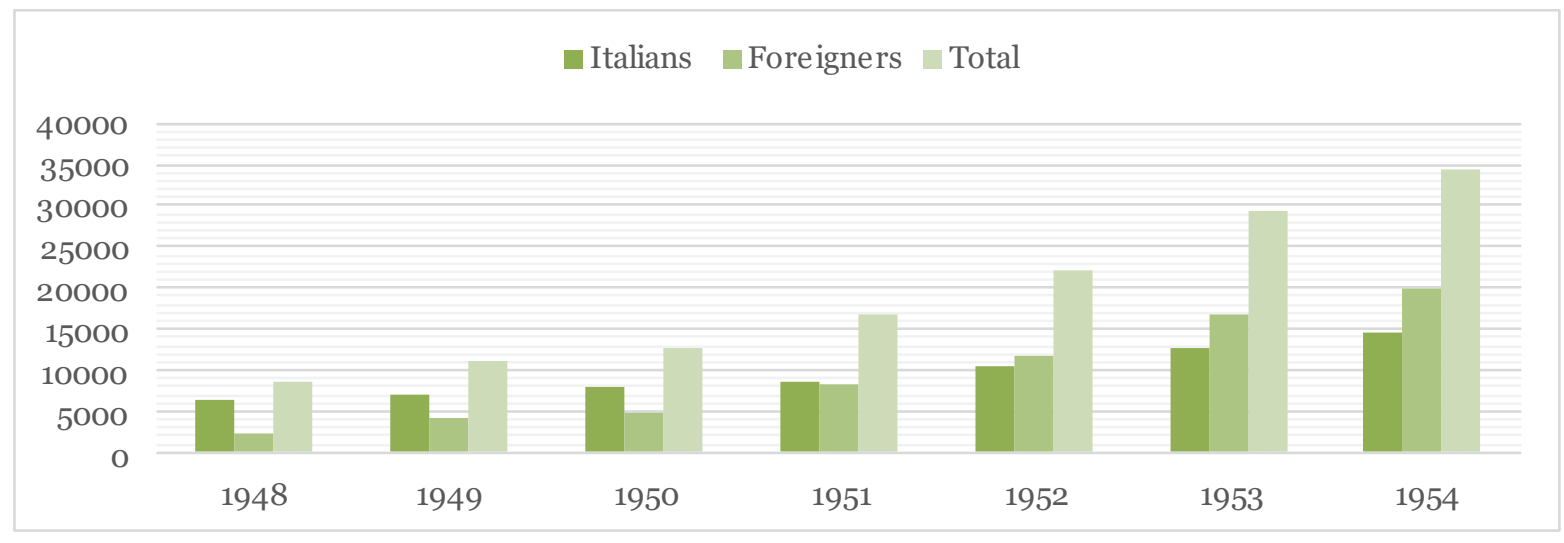

Graph 2. Arrivals of Italian and foreign tourists in Sirmione (1948-1954) - Source: ENIT, Statistica del turismo. Bollettino tecnico trimestrale dell'Ente Nazionale Industrie Turistiche, Roma, 1949-55 (data processed by the authors).

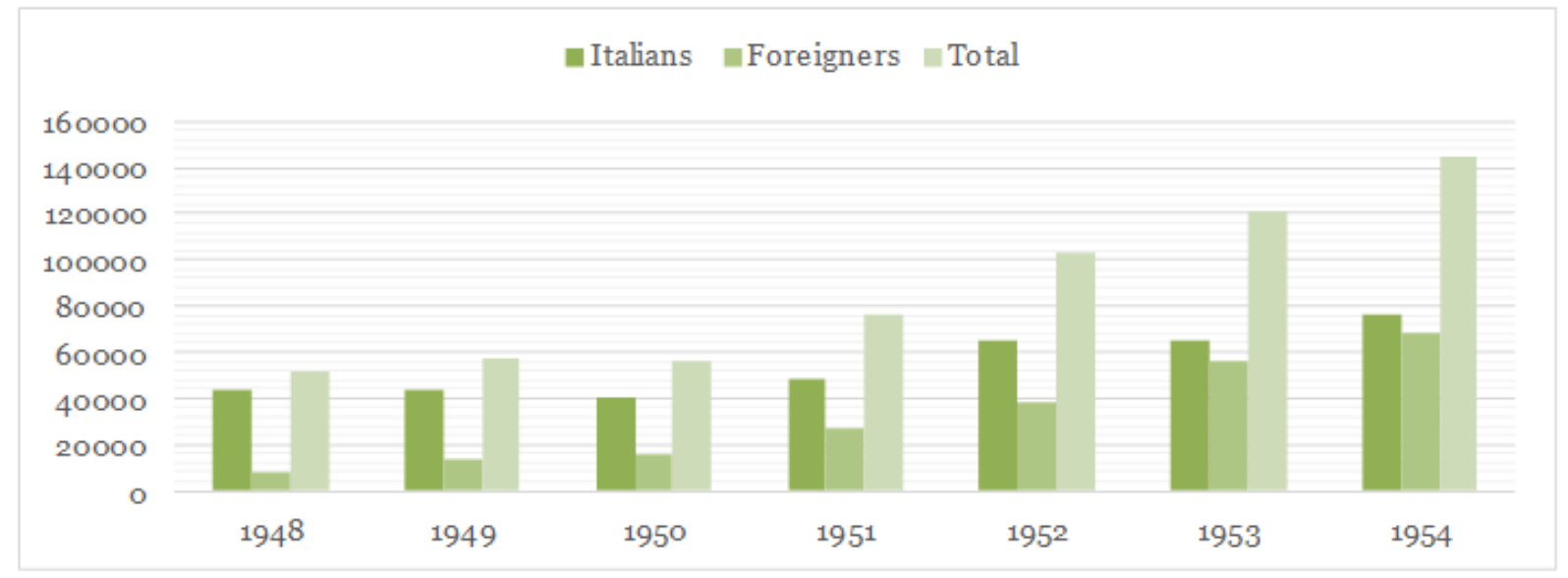

Graph 3. Nights of stay spent by Italian and foreign tourists in Sirmione (1948-1954) - Source: ENIT, op. cit., 1949-55 (data processed by the authors).

Significant improvements were achieved by SATGAS in 1953, when, despite rather adverse weather conditions, the attendance of patients and tourists exceeded forecasts. After years of poor financial results, the company had a profit of $£ 4,685,037$, out of which $£ 4,410,000$ were distributed to the shareholders for $6 \%$ of the par value of the shares. Also in 1953, investments were necessary to build SATGAS's administrative offices and, in the forecasts for the following years, the use of significant sums to keep on strengthening the structure of the company was envisaged. However, the board of directors was optimistic on the decrease of investments in function of the necessary reduction of the liabilities accumulated ${ }^{73}$.

The positive results achieved in 1953 were confirmed at the end of the 1954 and 1955 fiscal years. In the former, the company obtained a profit of $£ 7,808,912$, out of which $£ 5,292,000$ were

${ }^{73}$ ASCBs, RCT, n. 200, «VDB 5/5/1954». 
allocated to the shareholders for $6 \%$ of the par value of the shares; in the latter, $£ 7,056,000$ - out of a total profit of $£ 8,701,816$ - were distributed to the shareholders for $8 \%$ of the par value of the shares $^{74}$. A new phase was starting in the long postwar recovery process of SATGAS. If the period 1945-1953 was characterized by the reconstruction of the infrastructural base for the exploitation of the local spa spring and the reactivation of tourist flows, the following years marked the beginning of an expansion phase for the company, Sirmione and Lake Garda ${ }^{75}$. In 1954 the Hotel Fonte Boiola had its accommodation capacity increased with the construction of a new wing and the following year the same happened to the Grand Hotel Terme with the enlargement of its south wing. In 1956, important improvements were made to the Center for Rhinogenic Deafness that was enlarged with the construction of a connection between the two already existing bodies $^{76}$. On 22 December 1956, during an extraordinary general assembly, the shareholders approved a further substantial capital increase for $£ 44,100,000$ : the share capital rose from $£ 88,200,000$ to $£ 132,300,000$ through the issue of 294,000 new shares at the par value of $£ 150$. This operation was carried out with the aim of providing SATGAS with the necessary resources to finance the enlargement of the spa center, an intervention aimed at doubling the accommodation capacity and ensuring a significant improvement in the services provided ${ }^{77}$.

The performance of ROE (net income on average equity) and ROA (ЕВIT on average total assets) confirms the company's recovery dynamics. Graph 4 shows that the company had to face a difficult phase between 1946 and 1952 and it subsequently experienced continuous growth for the rest of the 1950s. In 1953, for the first time since the end of WWII, the two profitability indicators reached acceptable levels ( $5 \%$ for ROE and $8 \%$ for ROA), and then remained at excellent levels (ROE $>8 \%$, ROA $>10 \%$ ) until the further surge of 1961 . Widening the scope towards the decade that followed the years under scrutiny, or rather considering the first years of what can be defined as the phase of organized mass tourism, it is possible to verify how SATGAS' positive trend indeed continued. This allows us to glimpse a growth process of a company that was capable of renewal, both by rewarding the investments of the shareholders and by investing in new assets (Table 5).

\footnotetext{
${ }^{74}$ Ibidem, «VDB 3/5/1955»; Ibidem, «VDB 25/5/1956».

${ }^{75}$ ASTS, CSB, p. 35; PASINI, Pier Giuseppe, op. cit.

${ }^{76}$ ASTS, CSB, pp. 35-36.

${ }^{77}$ ASCBs, RCT, n. 200, «Nota di iscrizione 26/1/1957».
} 
Table 5. Main items of the SATGAs's balance sheets and profitability indicators.

\begin{tabular}{|c|c|c|c|c|c|c|c|c|c|}
\hline Fiscalyears & Capital stock & Assets & Fixed assets & Reserves & Equity & Netincome & Dividend & ROE & ROA \\
\hline 1946 & (£)600,000 & $27,286,873$ & $25,628,309$ & $21,801,339$ & $22,401,339$ & 384,958 & 0 & $1,72 \%$ & $3 \%$ \\
\hline 1947 & $10,500,000$ & $111,980,982$ & $75,460,278$ & $22,054,349$ & $32,554,349$ & $-395,356$ & 0 & $-1 \%$ & $2 \%$ \\
\hline 1948 & $10,500,000$ & $153,380,247$ & $144,294,067$ & $22,054,348$ & $32,554,348$ & $-284,028$ & 0 & $-1 \%$ & $0 \%$ \\
\hline 1949 & $63,000,000$ & $210,561,957$ & $186,821,910$ & $6,304,348$ & $69,304,348$ & $-394,320$ & 0 & $-1 \%$ & $5 \%$ \\
\hline 1950 & $63,000,000$ & $236,918,009$ & $225,243,004$ & $6,304,348$ & $69,304,348$ & 0 & 0 & $0 \%$ & $4 \%$ \\
\hline 1951 & $88,200,000$ & $231,011,083$ & $224,758,667$ & $6,304,348$ & $94,504,348$ & $1,239,100$ & 0 & $2 \%$ & $5 \%$ \\
\hline 1952 & $88,200,000$ & $243,467,360$ & $236,696,513$ & $6,304,348$ & $94,504,348$ & 0 & 0 & $0 \%$ & $5 \%$ \\
\hline 1953 & $88,200,000$ & $245,740,086$ & $238,383,267$ & $6,469,743$ & $94,669,743$ & $4,931,618$ & $4,410,000$ & $5 \%$ & $8 \%$ \\
\hline 1954 & $88,200,000$ & $251,107,268$ & $222,545,490$ & $6,991,361$ & $95,191,361$ & $7,808,912$ & $5,292,000$ & $8 \%$ & $9 \%$ \\
\hline 1955 & $88,200,000$ & $250,955,299$ & $237,861,272$ & $9,103,273$ & $97,303,273$ & $8,701,816$ & $7,056,000$ & $9 \%$ & $12 \%$ \\
\hline 1956 & $88,200,000$ & $251,335,731$ & $237,553,929$ & $10,344,089$ & $98,544,089$ & $9,430,553$ & $7,056,000$ & $10 \%$ & $11 \%$ \\
\hline 1957 & $132,300,000$ & $290,114,752$ & $262,708,731$ & $11,908,642$ & $144,208,642$ & $12,074,188$ & $10,584,000$ & $10 \%$ & $12 \%$ \\
\hline 1958 & $132,300,000$ & $313,409,993$ & $303,448,773$ & $12,588,830$ & $144,888,830$ & $14,352,939$ & $10,584,000$ & $10 \%$ & $12 \%$ \\
\hline 1959 & $132,300,000$ & $298,383,513$ & $286,437,603$ & $15,547,769$ & $147,847,769$ & $18,206,902$ & $15,876,000$ & $12 \%$ & $13 \%$ \\
\hline 1960 & $132,300,000$ & $297,020,820$ & $269,288,519$ & $17,068,671$ & $149,368,671$ & $17,119,059$ & $21,168,000$ & $12 \%$ & $13 \%$ \\
\hline 1961 & $132,300,000$ & $313,711,690$ & $298,849,320$ & $13,019,730$ & $145,319,730$ & $26,920,597$ & $26,460,000$ & $18 \%$ & $16 \%$ \\
\hline 1962 & $176,400,000$ & $421,650,373$ & $400,146,392$ & $36,539,335$ & $212,939,335$ & $30,107,012$ & $29,410,000$ & $17 \%$ & $16 \%$ \\
\hline 1963 & $176,400,000$ & $404,627,080$ & $387,571,078$ & $29,246,347$ & $205,646,347$ & $18,661,193$ & $17,640,000$ & $9 \%$ & $11 \%$ \\
\hline 1964 & $176,400,000$ & $444,927,999$ & $412,878,235$ & $33,529,874$ & $209,929,874$ & $18,378,468$ & $17,640,000$ & $9 \%$ & $11 \%$ \\
\hline 1965 & $176,400,000$ & $438,787,673$ & $398,119,262$ & $37,416,479$ & $213,816,479$ & $36,036,066$ & $21,168,000$ & $17 \%$ & $17 \%$ \\
\hline 1966 & $176,400,000$ & $438,897,141$ & $390,904,375$ & $52,284,545$ & $228,684,545$ & $40,565,104$ & $29,400,000$ & $18 \%$ & $22 \%$ \\
\hline 1967 & $176,400,000$ & $494,743,826$ & $444,830,539$ & $63,449,649$ & $239,849,649$ & $53,018,101$ & $35,280,000$ & $23 \%$ & $19 \%$ \\
\hline 1968 & $176,400,000$ & $543,190,396$ & $462,703,287$ & $132,455,110$ & $308,855,110$ & $52,511,128$ & $47,040,000$ & $19 \%$ & $20 \%$ \\
\hline 1969 & $176,400,000$ & $552,547,334$ & $458,844,473$ & $137,926,238$ & $314,326,238$ & $46,414,629$ & $58,800,000$ & $15 \%$ & $22 \%$ \\
\hline
\end{tabular}

Source: ASCBs, RCT, n. 200 (data processed by the authors). 
Table 6. Main items of the SATGAs's income statements.

\begin{tabular}{|c|c|c|c|c|c|c|c|c|c|c|}
\hline \multirow{3}{*}{$\begin{array}{l}\text { Fiscal } \\
\text { years }\end{array}$} & \multicolumn{5}{|c|}{ Revenues } & \multicolumn{4}{|c|}{ Costs } & \multirow{3}{*}{ EBIT } \\
\hline & \multicolumn{3}{|c|}{ Hotels } & \multirow{2}{*}{ Spa } & \multirow{2}{*}{ Others $^{78}$} & \multirow{2}{*}{ Administration } & \multirow{2}{*}{ Maintenance } & \multirow{2}{*}{ Amortizations } & \multirow{2}{*}{ Others $^{79}$} & \\
\hline & Sirmione & Terme & FonteBoiola & & & & & & & \\
\hline 1946 & \multicolumn{3}{|c|}{ (£)3,369,492 } & $2,293,236$ & 214,159 & $1,348,635$ & $2,337,938$ & $1,474,454$ & 0 & 715,860 \\
\hline 1947 & \multicolumn{3}{|c|}{$9,995,627$} & $1,776,338$ & 404,337 & $3,528,475$ & $1,583,614$ & $4,987,910$ & 93,095 & $1,983,208$ \\
\hline 1948 & \multicolumn{3}{|c|}{$12,205,641$} & $7,636,232$ & 117,763 & $4,742,885$ & $1,044,697$ & $8,360,169$ & $6,095,913$ & $-284,028$ \\
\hline 1949 & \multicolumn{3}{|c|}{$13,572,808$} & $13,744,179$ & 375,414 & $8,303,339$ & 0 & $9,796,749$ & 0 & $9,592,313$ \\
\hline 1950 & \multicolumn{3}{|c|}{$9,020,580$} & $11,613,180$ & 767,491 & $8,765,097$ & 0 & $2,116,917$ & 0 & $10,519,237$ \\
\hline 1951 & \multicolumn{3}{|c|}{$18,021,637$} & $15,779,063$ & 152,033 & $10,669,741$ & 0 & $11,620,770$ & 0 & $11,662,222$ \\
\hline 1952 & \multicolumn{3}{|c|}{$19,099,493$} & $13,133,063$ & 387,168 & $13,868,890$ & 0 & $6,174,797$ & 0 & $12,576,037$ \\
\hline 1953 & $7,084,014$ & $12,404,231$ & $6,683,677$ & $31,189,446$ & 572,762 & $20,576,239$ & $1,218,991$ & $15,540,554$ & 42,449 & $20,555,897$ \\
\hline 1954 & \multicolumn{4}{|c|}{$55,756,633$} & 426,482 & $14,876,898$ & $3,126,866$ & $15,644,351$ & 26,350 & $22,508,650$ \\
\hline 1955 & \multicolumn{4}{|c|}{$59,451,185$} & 469,183 & $12,968,306$ & 422,020 & $17,352,907$ & 43,256 & $29,133,879$ \\
\hline 1956 & \multicolumn{4}{|c|}{$61,628,037$} & 582,680 & $13,541,731$ & $2,405,420$ & $18,848,248$ & 11,112 & $27,404,206$ \\
\hline 1957 & \multicolumn{4}{|c|}{$69,048,704$} & 701,721 & $13,250,607$ & $2,649,936$ & $18,879,122$ & 302,426 & $34,668,334$ \\
\hline 1958 & $5,886,502$ & $13,702,629$ & $8,159,135$ & $44,344,180$ & 681,678 & $11,016,786$ & $3,736,535$ & $21,370,787$ & 82,916 & $36,567,100$ \\
\hline 1959 & $19,131,647$ & $16,374,489$ & $10,827,628$ & $43,765,143$ & $1,249,115$ & $20,260,772$ & $1,296,150$ & $30,279,582$ & 10,441 & $39,501,077$ \\
\hline 1960 & $17,984,734$ & $21,681,948$ & $8,188,324$ & $37,658,508$ & $1,149,817$ & $19,580,959$ & 1,697,517 & $27,663,641$ & 115,207 & $37,606,007$ \\
\hline 1961 & $17,401,054$ & $20,886,064$ & $8,610,873$ & $45,674,566$ & $2,181,863$ & $21,343,975$ & $2,014,764$ & $22,539,028$ & 64,038 & $48,792,615$ \\
\hline 1962 & $20,766,157$ & $26,114,998$ & $9,172,780$ & $59,037,975$ & $3,722,406$ & $24,519,782$ & $2,199,144$ & $25,652,035$ & 139,863 & $66,303,492$ \\
\hline 1963 & $19,540,340$ & $19,497,312$ & $10,134,689$ & $51,966,289$ & $4,510,519$ & $26,570,904$ & $2,435,129$ & $30,812,410$ & 134,957 & $45,695,749$ \\
\hline 1964 & $19,174,714$ & $14,868,453$ & $8,911,202$ & $76,496,447$ & $4,903,749$ & $33,959,390$ & $2,806,595$ & $38,811,916$ & 381,614 & $48,395,050$ \\
\hline 1965 & $25,044,736$ & $18,889,062$ & $12,787,322$ & $99,578,735$ & $5,665,384$ & $47,210,790$ & $2,329,927$ & $39,499,765$ & 79,752 & $72,845,005$ \\
\hline 1966 & $21,996,682$ & $20,386,339$ & $9,464,166$ & $127,245,188$ & $5,861,196$ & $49,949,347$ & $2,181,791$ & $36,071,585$ & $1,133,440$ & $95,617,408$ \\
\hline 1967 & $11,744,753$ & $9,473,328$ & $9,149,426$ & $159,446,668$ & $4,960,073$ & $55,686,293$ & $2,778,890$ & $40,020,819$ & 234,570 & $96,053,676$ \\
\hline 1968 & $17,176,281$ & $15,243,788$ & $14,618,803$ & $161,525,450$ & $5,539,795$ & $54,588,094$ & $2,952,689$ & $43,480,103$ & $4,473,203$ & $108,610,028$ \\
\hline 1969 & $16,134,757$ & $23,771,400$ & $15,392,654$ & $186,154,406$ & $5,849,698$ & $58,985,658$ & $4,476,328$ & $57,827,307$ & $1,714,755$ & $124,298,867$ \\
\hline
\end{tabular}

Source: ASCBs, RCT, n. 200 (data processed by the authors).

${ }^{78}$ Financial gains not included.

${ }^{79}$ Financial expenses and taxes not included. 


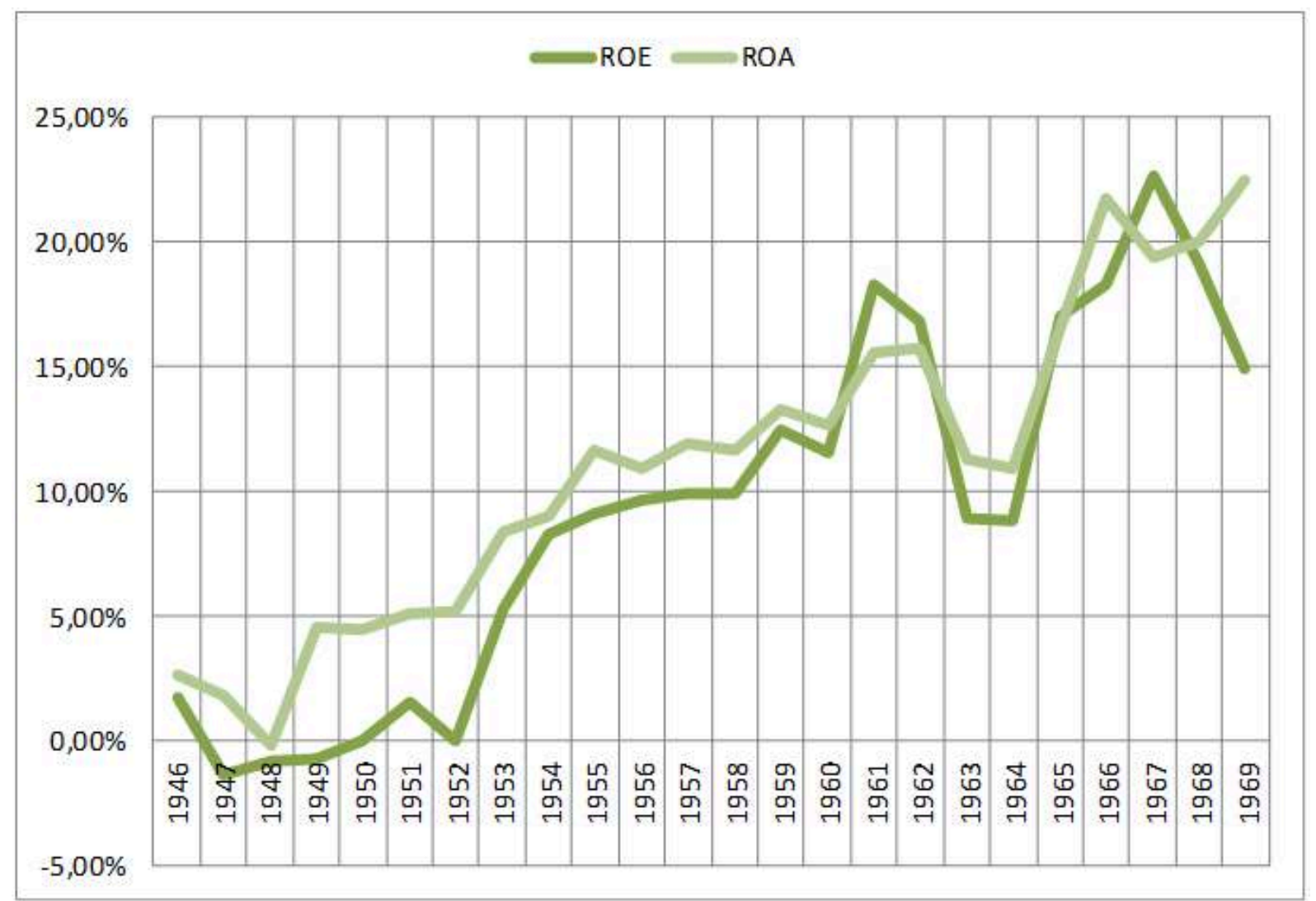

Graph 4. Profitability indicators - Source: ASCBs, RCT, n. 200 (data processed by the authors).

Unfortunately, from the income statements kept at the Chamber of Commerce of Brescia it is not possible to quantify the impact of each accommodation facility on the net income of SATGAS, since the expenses were categorized generically according to the items "Administration", "Maintenance", etc. However, it is possible to observe the incidence that the 3 hotels and spa facilities had on the company's revenues (Table 6). In this sense, the item "Spa" and, indirectly, the previously illustrated investments for the construction of a new plant were of paramount importance. On the other hand, as regards the hotels, despite the lack of distinction for individual structures for many fiscal years, we notice that the role played by the hotels Sirmione and Terme was predominant, though Boiola still maintained a not-negligible relevance.

Such a significant growth of SATGAS was accompanied by an equally successful development of the whole Sirmione context and of the rest of Lake Garda. During the Fifties, on all three shores of Benaco - Brescia, Verona, Trento - the number of holidaymakers from all over Europe, especially from Germany, continued to grow. Benaco was becoming to all intents and purposes a tourist destination for families, where it was possible to choose from a wide range of accommodation facilities offering services, and consequently prices, for all budgets ${ }^{80}$.

\footnotetext{
${ }^{80}$ AVANZINI, Patrizia, op. cit.; «L'afflusso dei turisti stranieri ha superato tutti i precedenti», in Corriere della Sera, 21 April 1957, p. 8; CERVI, Mario, «Il Garda di buon umore», in Corriere della Sera, 21 July 1959, p. 7; ID.,
} 


\section{Conclusions}

The case study examined in this essay gives insights into the difficult challenges that Italian tourism companies had to face at the end of WWII. As a consequence of the block of tourist flows and the deterioration of the infrastructures that the conflict had caused, the operators of the sector had to undertake a reconstruction phase which required huge resources and could not be taken for granted. Furthermore, since the late Forties, the competitive scenario was assuming new contours that became clearer during the Fifties. Tourism was starting to involve a growing number of people, increasing its importance in the national balance of payments and was recognized as a relevant factor in international relations: tourism, in other words, was taking decisive steps towards the acquisition of a mass and internationalized dimension ${ }^{81}$.

After 25 April 1945, SATGAS had to deal with financial statements weighed down by substantial liabilities, as well as with destroyed or, at best, deteriorated hotels and spa facilities. The new shareholders had to undertake significant efforts in terms of material reconstruction and financial commitment. Providing resources mainly through repeated and substantial capital increases, the new shareholders and board of directors relaunched the company following a strategy characterized by a forced choice, but also by forward-looking intuitions that proved to be fundamental for the success of the following years. On the one hand, the forced choice was the renovation of the real estate assets of SATGAS, without which the recovery would not have been possible. On the other hand, the forward-looking intuitions were represented by the overall increase in the quality of facilities and services with respect to prewar standards, but also by the pursuit of diversification and innovation.

Diversification took the form of a plural accommodation and spa offer, characterized by facilities of different sizes and qualities. Through the interventions of reconstruction and renewal, not only the Hotel Fonte Boiola, Hotel Sirmione and Grand Hotel Terme were improved in terms of comfort, furnishings and services, but they also acquired a better defined position within the SATGAS accommodation offer. In other words, the three hotels became structures able to address specific market segments and intercept different clienteles, with different needs and spending capacities ${ }^{82}$. In a phase of reconstruction and approach to a tourism aimed at involving

«Il Garda è diventato un "lago per famiglie"», in Corriere della Sera, 3 August 1965, p. 4.

${ }^{81}$ BATTILANI, Patrizia, Vacanze di pochi, vacanze di tutti. L'evoluzione del turismo europeo, Bologna, Il Mulino, 2009, pp. 147-154; LEONARDI, Andrea, La ripresa dell'offerta turistica nel secondo dopoguerra: il turismo alpino verso un nuovo take-off, in LEONARDI, Andrea, BONOLDI, Andrea (a cura di), La rinascita economica dell'Europa. Il piano Marshall e l'area alpina, Milano, FrancoAngeli, 2006, pp. 161-194; ID., Turismo e bilancia dei pagamenti nel secondo dopoguerra: le valutazioni dell'Eca e dell'Oece, in COVA (a cura di), Il dilemma dell'integrazione. L'inserimento dell'economia italiana nel sistema occidentale (1945-1957), Milano, FrancoAngeli, 2008, pp. 211-234. ${ }^{82}$ On this see also: SALVELI, Guido (a cura di), op. cit., pp. 118-120; AGENZIA DI VIAGGI F.LLI MOLINARI (a cura di), Guida turistica del lago di Garda, Brescia, Morcelliana, 1958, pp. 98-99; MAZZA, Attilio, Guida pratica 
less demanding tourists with less purchasing power, not only did SATGAS modernize its higherlevel facilities, but it also showed a decisive focus on a medium level structure like the Hotel Fonte Boiola. After all, it is probably no coincidence that the subsequent phase of expansion of the company, in the mid-Fifties, began with an important intervention on this very hotel.

In terms of innovation, the attention of the company was focused on spa facilities. On the basis of high quality spa plants, SATGAS acquired a well-defined position in the Italian spa market, imposing itself as a point of reference in specific sectors, i.e. the treatment of rhinogenic deafness. The company stood out not only by purchasing cutting-edge tools, machinery and plants, but also by producing innovation. As a matter of fact, through the work of one of its employees, Guido Bianchi Porro, the company patented a new equipment to apply the humages technique to the treatment of rhinogenic deafness and built a specialized center for this type of treatment. Other examples of how SATGAS tried to operate on the technological and scientific frontier were the establishment of a scientific committee for the study of the spa water of the Boiola spring (composed of professors from the universities of Bologna, Milan, Padua and Pisa), and the replacement of metal pipes with Fibronit pipes (with pozzolanic cement and centrifuged asbestos) $)^{83}$.

A crucial and emblematic element of the diversification and innovation strategies pursued by the company was the new spa center. Through its construction, the company could count on a cutting-edge facility for spa treatments and facilitated a synergistic exploitation of the resources in the area. Indeed, the new center was designed and equipped to receive guests and patients also from other accommodation facilities of the Lake. This way, SATGAS obtained two results: the first one was to enlarge its potential customer base in both quantitative and qualitative terms, taking advantage of the accommodation capacity of all kinds of tourism structures, including pensions, campsites and hotels of different categories. The second one was that of making itself and the town of Sirmione crucial hubs in the dynamics of the tourist flows in the area: they became driving elements of a region that bet its future on tourism and was about to greet unprecedented tourists flows in terms of numbers and needs ${ }^{84}$.

The picture that emerges of SATGAS is that of a company that was able to recover from the difficulties of WWII by following a similar path, albeit with a few differences, to that undertaken in the same phase by other successful large Italian tourism enterprises ${ }^{85}$. Even the spa company considered in this essay, as well as the other thriving large tourist companies of the second post-

\footnotetext{
del lago di Garda, Brescia, Brescia P.R., 1970, pp. 21-22.

${ }^{83}$ MELLUSO, Antonio, Sirmione: climatico termale turistico, Como, Brunner, 1975; ASTS, CSB, p. 35.

${ }^{84}$ AVANZINI, Patrizia, op. cit.; OSELINI, Maria Paola, Sirmione: storia ed economia del suo turismo, Tesi di diploma, Scuola Superiore di Turismo, Verona, a.a. 1990/1991.

${ }^{85}$ BATTILANI, «L'industria alberghiera italiana fra Ottocento e Novecento: la fragilità di lungo periodo della grande impresa», cit.
} 
war period, showed a particular attention to a high-level clientele, characterized by a high spending capacity. As demonstrated by the investments made in the Terme and Sirmione hotels and in the center for the treatment of rhinogenic deafness, the strategy was to go in search of market niches associated with luxury and excellence. However, SATGAS was also able to distinguish itself by enriching its offer with two other fundamental elements: 1) a second-class hotel - Fonte Boiola - in some ways similar to one of the many small-medium family-run structures that have been identified as the hallmark of the Italian hotel industry; 2) a new and functional spa capable of intercepting and interacting with the large flow of tourists that Lake Garda was attracting during the second half of the twentieth century.

Although limited to an initial exploration based on profitability indices, this paper has also highlighted SATGAS's ability to obtain good results in the phase immediately following that of spontaneous mass tourism specifically considered in this essay. These results, which seem to give further ground to the idea of SATGAS as a successful company, not only invite new studies that can better contextualize them, but also suggest new research questions as regards the evolution of the company in the phase of organized mass tourism. What management difficulties did the coexistence of two types of tourism impose on the company? Which type of tourist was the rest of the Garda context orienting towards ${ }^{86}$ ? What were the implications in terms of environmental sustainability of the tourist success of SATGAS, Sirmione and the rest of the Lake ${ }^{87}$ ? It would be interesting to try to find an answer to all these questions in future studies, in an attempt to enrich the growing scientific debate on the historical evolution of the Italian hotel industry. The answers could be found not only by considering issues of business history, but also by analyzing aspects of the regional history to which the company belongs ${ }^{88}$.

\footnotetext{
${ }^{86}$ MARCHI, Cesare, "Sirmione al bivio tra il turismo di massa e di "élite"», in Corriere d'informazione, 25-26 July 1966, p. 5; MARINI, Bruno, «Il dilemma turistico del Garda», in Corriere della Sera, 4 September 1970, p. 10.

${ }^{87}$ RHO, Franco, «"Soffocati” il lago e le sponde dal dilagare del cemento Sangue il turismo sul Garda», in Corriere d'informazione, 1-2 July 1967, p. 9; «Rapporto sul Garda che cambia», in Corriere della Sera, 4 March 1969 , p. 10.

${ }^{88}$ On regional tourism and its historiographical and methodological issues see: HUMAIR, Cédric, KNOLL, Martin, TISSOT, Laurent, «How to Deal with Regional Tourism? Historical (and Interdisciplinary) Reflections», in Zeitschrift für Tourismuswissenschaft, IX, 1/2017, pp. 5-31.
} 


\section{THE AUTHORS}

Riccardo SEMERARO (1988) is research assistant of Economic History at the Catholic University of the Sacred Heart of Brescia, Department of History and Philology. He received his Ph.D. in Economics and Management from the University of Verona in 2017. He is interested in the Late Modern and Contemporary Ages and, in particular, his research interests concern the history of firearms production, the history of tourism, industrial districts and clusters, as well as the socioeconomic comparison of Italy and Spain (https://orcid.org/0000-0003-4181-1064).

URL: < http://www.studistorici.com/progett/autori/\#Semeraro >

Maria Paola PASINI, Ph.D. in Economic History, is adjunct professor of Tourism History, Territorial Marketing and Marketing in SMEs at the Catholic University of the Sacred Heart of Milan and Brescia. She is president of the Centro Studi e Docuentazione "Giuseppe Bonelli" headquartered at the State Archives of Brescia, as well as member of both the Centro di Ricerca sulla Cultura e Narrazione del Viaggio (CENVI) and the scientific committee of the Archivio Storico della Resistenza Bresciana e dell'Età Contemporanea (https://orcid.org/0000-0002-1495-2542).

URL: < http://www.studistorici.com/progett/autori/\#Pasini > 